\title{
Triple Helix as a Strategic Tool to Fast-Track Climate Change Adaptation in Rural Kenya: Case Study of Marsabit County
}

\author{
Izael da Silva, Daniele Bricca, Andrea Micangeli, Davide Fioriti, and \\ Paolo Cherubini
}

\section{Contents}

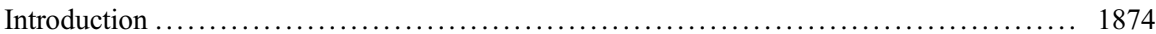

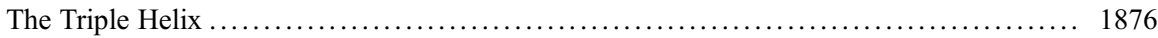

The Role of the University ........................................... 1876

The Relationships between University, Government, and Industry ................ 1877

Triple Helix in Africa ................................................... 1877

Triple Helix for Sustainability and Climate Change .......................... 1879

Energy Access and Climate Change in Kenya ................................... 1880

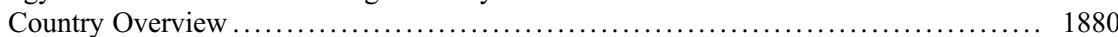

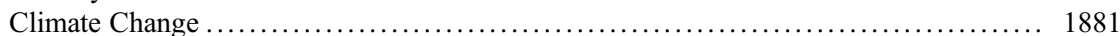

Rural Electrification in Kenya .......................................... 1881

Case Study - Marsabit County, Kenya .................................... 1883

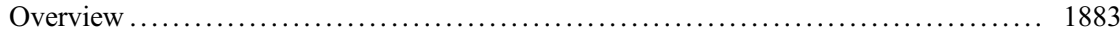

Energy Access in Marsabit ............................................ 1884

This chapter was previously published non-open access with exclusive rights reserved by the Publisher. It has been changed retrospectively to open access under a CC BY 4.0 license and the copyright holder is "The Author(s)". For further details, please see the license information at the end of the chapter.

I. da Silva $(\bowtie)$

Strathmore University, Nairobi, Kenya

e-mail: idasilva@strathmore.edu

D. Bricca

Sapienza University of Rome, Rome, Italy

A. Micangeli

DIMA, Sapienza University of Rome, Rome, Italy

e-mail: andrea.micangeli@uniroma1.it

D. Fioriti $\cdot$ P. Cherubini

DESTEC, University of Pisa, Pisa, Italy

e-mail: davide.fioriti@ing.unipi.it; paolo.cherubini@ing.unipi.it

(C) The Author(s) 2021

W. Leal Filho et al. (eds.), African Handbook of Climate Change Adaptation, https://doi.org/10.1007/978-3-030-45106-6_76 


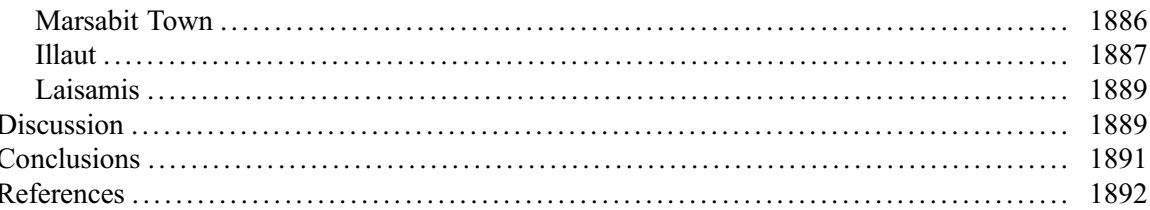

\section{Abstract}

The lack of affordable, clean, and reliable energy in Africa's rural areas forces people to resort to poor quality energy source, which is detrimental to the people's health and prevents the economic development of communities. Moreover, access to safe water and food security are concerns closely linked to health issues and children malnourishment. Recent climate change due to global warming has worsened the already critical situation.

Electricity is well known to be an enabler of development as it allows the use of modern devices thus enabling the development of not only income-generating activities but also water pumping and food processing and conservation that can promote socioeconomic growth. However, all of this is difficult to achieve due to the lack of investors, local skills, awareness by the community, and often also government regulations.

All the above mentioned barriers to the uptake of electricity in rural Kenya could be solved by the coordinated effort of government, private sector, and academia, also referred to as Triple Helix, in which each entity may partially take the other's role. This chapter discretizes the above and shows how a specific county (Marsabit) has benefited from this triple intervention. Existing government policies and actions and programs led by nongovernmental organizations (NGOs) and international agencies are reviewed, highlighting the current interconnection and gaps in promoting integrated actions toward climate change adaptation and energy access.

\section{Keywords}

Triple helix $\cdot$ Rural electrification $\cdot$ Wealth creation $\cdot$ Climate change adaptation $\cdot$ Suitable policies and regulations

\section{Introduction}

Energy poverty is a serious concern in developing countries which often are the ones to bear most of the negative consequences of climate change. Currently, about 2.6 billion people have no access to clean cooking and about 850 million do not have access to electricity (International Energy Agency (IEA) 2019a). Some of these consequences are deficient healthcare systems, lack of access to education, and lower economic growth leading to political instability and migratory flows. Despite of international agencies' support and local government fund allocation, still 500 million people are expected to have no access to electricity by 2030 (International 
Energy Agency (IEA) 2019b). All of the above are worsened by climate upheaval such as droughts, floods, and rain shortage (Trenberth et al. 2014).

Energy, food, and water are scarce and of low quality for people living in rural areas of developing countries. Food insecurity affects about $10-11 \%$ of people worldwide with peaks of $30 \%$ in east Africa (FAO 2019), or even beyond as confirmed by the surveys performed by Fraval et al. (2019). Food is often cooked without proper cooking facilities, often with firewood or charcoal, and exhaust gases are released inside the rooms without a proper ventilation system (Goldemberg et al. 2018). This affects the healthy conditions of inhabitants and especially children (Smith et al. 2014). Moreover, according to UNICEF, only about $30 \%$ of people in Sub-Saharan Africa had access to safely managed drinking water in 2017, whereas $30 \%$ of them had limited or inadequate access (UNICEF and WHO 2019). Often, water is far from settlements and unemployed people, usually children or women, have to walk several kilometers a day for procuring water for the family (UNICEF and WHO 2019). Furthermore, lack of water and scarce hygiene can facilitate the widespread of diseases (UNICEF and WHO 2019). Energy poverty, hunger, and no access to clean water are extremely correlated not only among themselves but also with low hygiene and low development rates (FAO 2019).

Electricity is widely recognized as a major determinant for social and economic development (Gambino et al. 2019), as it can allow the use of modern devices to be used for commercial or small industrial activities. The attention that African governments have paid on fostering access to electricity is justified by the correlation between electricity and income, as well as with the social development index (Zhang et al. 2011; FAO 2019). In fact, access to modern energy can have significant effects on poverty and access to water and reduce hunger, which are all significant priorities stated by United Nations (International Energy Agency (IEA) 2019a). Renewable energy-based electricity can provide reduction in $\mathrm{CO}_{2}$ emissions by reducing the recourse to coal-based electricity in communities already reached by the national grid, by hybridizing with renewable sources existing mini grids mostly powered by diesel gensets (Micangeli et al. 2017), and by displacing the use of traditional fuels for lighting (Micangeli et al. 2017; Ambition to Action 2019). As an example, smallscale irrigation can contribute to income diversification and livelihood resilience (Murphy and Corbyn 2013).

Governments in developing countries often cannot enforce a fast development of rural electrification alone, due to lack in financial resources, know-how, or human capacity (Franz et al. 2014). On this regard, the involvement of the private sector as well as know-how holders, such as universities and international entities, is considered crucial (Franz et al. 2014), also to prevent the consequences that climate change may cause on already critical situations. Recent modern business models exploit the benefits of the integrated approach of the so-called energy-water-food nexus, by which the developer brings in electricity service, which in turn avails services like water and food through irrigation (Res4Africa 2019).

Universities produce knowledge and promote long-term growth through innovation and technology transfer to private and public sector. On the other hand, governments develop guidelines and policies in order to guide the industry toward 
the long-term social benefits for society. By considering the above, it is clear that significant synergies among the three entities can be explored and this cooperation is called "Triple Helix" (Leydesdorff and Etzkowitz 1995; Carayannis and Campbell 2010), which is proposed in this chapter as a tool to foster climate change adaptation in Kenya, with the special attention to the Marsabit County, an area heavily hit by climate change and subject to draughts and floods.

In section "The Triple Helix," the Triple Helix concept is detailed, including applications for rural electrification, Africa, and sustainability concerns. In sections "Energy Access and Climate Change in Kenya" and "Case Study - Marsabit County, Kenya," the case study is introduced and in section "Discussion" the major discussions are proposed. Finally, the conclusions are made.

\section{The Triple Helix}

The concept of Triple Helix (TH) has been proposed in the 1990s (Leydesdorff and Etzkowitz 1995) as a new framework to conceptualize relationships between university, government, and industry, to address the need of organizational innovation in a knowledge-based society. Innovation, defined as "reconfiguration of elements into a more productive combination" (Etzkowitz 2008), requires, in this view, a central role of the university, since innovation is not merely attributable to new product development by the industrial sector (Etzkowitz 2008).

\section{The Role of the University}

It has been acknowledged, in a seminal work made by Gibbons et al. (Gibbons et al. 1994), that the very production of knowledge has transitioned from a "traditional" framework, labeled Mode 1, driven and administered by classic academia in a disciplinary context, to a new mode, labeled Mode 2. In this new framework, knowledge is produced in the context of application, by a variety of actors coming from different disciplines, in an interactive relationship with society as a whole, both in defining the problems and research goals, and in diffusion of results. In recognition of the different way of knowledge production, and the role that it acquired in innovation, the university reshaped its mandate. The first modern universities were created in the twelfth century with the purpose of preservation and dissemination of knowledge (teaching mission). In the nineteenth century a second mission - research - was added, and more recently a third mission, that of contribution to economic development (Etzkowitz 2003). This mission requires an entrepreneurial model to be adopted by academia, that is not limited to preservation and transmission of knowledge but is involved proactively in technology transfer and incubation activities (Etzkowitz 2003). Furthermore, Carayannis et al. proposed the concept of "Mode 3" in which knowledge is produced by pluralism and diversity of knowledge, in a Triple, Quadruple, or Quintuple Helix framework, also including a combination of modes 1 and 2 (Carayannis and Campbell 2010). 


\section{The Relationships between University, Government, and Industry}

The relationships among these three entities can be visualized as lying among two extremes: a centralized model where the government guides science policy and industrial development ("statist model") or a situation of very limited interaction, where each entity attains its core mandate separately from the others ("laissez-faire model") (Etzkowitz 2008). To visualize the interactions typical of the TH, Fig. 1 shows the "field interaction model" proposed by Eskowitz (Etzkowitz 2008) that schematizes government, industry, and university as three spheres with an inner core, representing their specific functions, and outer cores that overlap as each entity "takes the role of the other on a synergetic manner."

It is argued that the TH concept could act as a flywheel in pursuing a path of compliance with the objectives set out by the Sustainable Development Goals (SDGs) for rural areas of developing countries. However, TH dynamics has usually referred to a context of discontinuous innovation in advanced technological sectors such as ICT (Information and Communication Technology), semiconductors, or biotechnology. The most iconic example of regional development led by TH dynamics is the one of Silicon Valley, an international hub for high-tech companies animated by Stanford University's knowledge development (Etzkowitz 2012). In the following section, we will look at how the TH framework has been applied and discussed in the African context and how it has been integrated or reformulated to embed the sustainability issues underpinned by the SDGs.

\section{Triple Helix in Africa}

Rarely TH applications have been found in Africa. As noted by Outamha and Belhcen (Outamha and Belhcen 2020), the core mission of university in the

Fig. 1 Triple Helix field interaction model (Etzkowitz 2008)

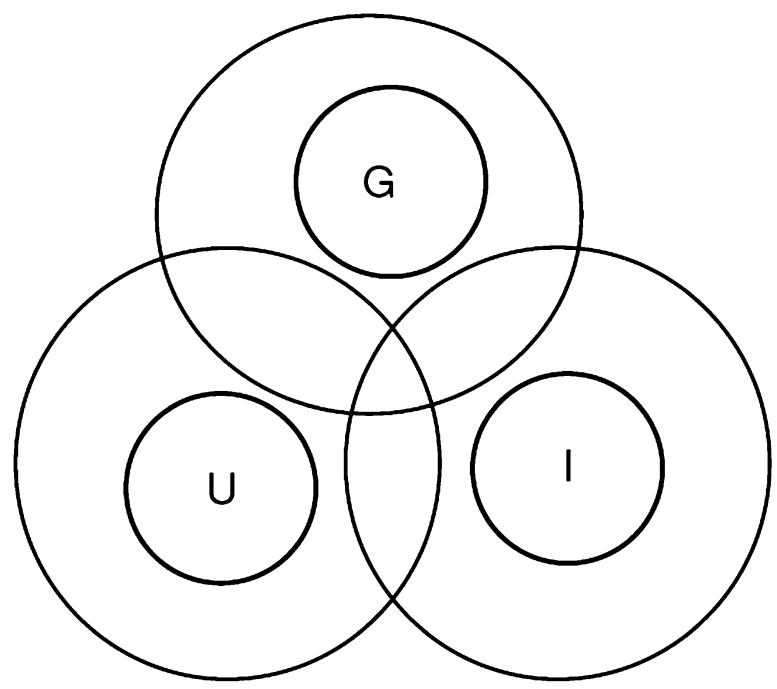


continent is still the provision of human capital to industry and government, hence it is not on par with the global standards of knowledge-based societies. The historical reasons for this have been identified by some authors in the focus on mass primary and universal education over higher education in aid programs, at the expense of higher education (Dzisah 2011).

In Outamha and Belhcen (2020), a list of challenges that interconnections between university and industry are facing in Africa is given and shown in Fig. 2, together with the challenges for the implementation of mini-grids for rural electrification (African Development Bank Group et al. 2016). The different points are shown below:

- The lack of data regarding mini-grid projects reflects the lack of interest and commitment from industry to share information and collaborate in knowledge creation and diffusion, aggravated by confidentiality and property right concerns.

- Lack of capacity for mini-grid development reflects the lack of interest and lack of communication platforms to socially disseminate results of application-oriented curricula (Perez-Arriaga et al. 2018).

- Lack of access to finance reflects the lack of entrepreneurial prowess on the university side, resulting in lack of interest and aggravated by lack of mutual trust and lack of communication platforms bringing together the other two sectors.

- Gaps in policy and regulation reflect that academic curriculums in universities, prioritizing human capital formation, tend to not address the training of leaders that can give an answer to structural problems undermining the development of countries.

- Lack of viable business models is also a consequence of a lack of coordinated effort from governments planning for electrification plans, state-owned utilities, private actors, and academics in analyzing and reviewing current on-field experiences and contributing to develop improved models, overcoming contradictions

Barriers to $\mathrm{TH}$ Development in $\mathrm{SSA}$
-Lack of interest and commitment
-Lack of mutual trust
- - Acquisition versus exploitation

Fig. 2 Proposed linkages between barriers to university-industry linkages in SSA (Outamha and Belhcen 2020), on the left, and the barriers to development of Green Mini-Grids in SSA (African Development Bank Group et al. 2016), on the right 
between knowledge acquisition by universities and commercial exploitation by private sector players.

The adoption of a TH framework has been proposed for the energy sector in SSA, specifically for the development of photovoltaic installations in Uganda (Da Silva and Wassler 2011). There are examples of spin-off companies operating in the Solar Home System sector in SSA, such as BBOXX (from Imperial College of London) and Azuri Technologies (from Cambridge University) (Bagley et al. 2018). By looking at these two companies, it is worth highlighting the issue of the "localization" of TH dynamics for the specific case, as they are firms born from non-African universities but working on African ground with local government and international entities.

In tackling the issue of electricity access conjointly with the food and water security and climate change adaptation issues, it has to be kept in mind that is a sector of intervention with serious concerns of bankability of investments (Kottász and Draeck 2017), especially for the realization of mini-grids, and in which international organizations and NGOs play a leading role. Therefore, there is, on the one hand, a multiplicity of stakeholders (i.e., NGOs) that are not present in the classic TH model, and on the other hand, a geographical globalization by which interventions directed at rural communities of developing countries involve not only local governments, universities, and industries but also international counterparts, mobilized by the concerns and goals of international agencies and non-profit organizations. As an example, in Moore et al. (2015) a program for ICT (Information and Communication Technology) education for Rwandan teachers is discussed as a possible example of TH development, albeit "loosely" not only because of the leading role of the local government in proposing the program, supported by local academia and privates, but also for the role of UNESCO and foreign cooperation agencies, factors that "are missing from the model."

\section{Triple Helix for Sustainability and Climate Change}

The original TH model did not entail sustainability issues linked to innovations. Etzkowitz and Zhou (Etzkowitz and Zhou 2006) proposed to consider a second TH system, one of university, government, and public to act as a counterbalance to technological innovations introduced by the university-government-industry triad, by representing the "dynamic of controversies over technological innovation." This picture of twin helices was chosen to maintain the triadic nature of each one, whereas other authors have proposed to the inclusion of a fourth helix - representing civil society, in form of NGOs or other associations of citizens - and a fifth helix, accounting for the natural environment of society (Carayannis et al. 2019). A quadruple helix approach has been proposed specifically for Africa (Kimatu 2015), as it could provide the needed "sustainable innovation ecosystem" to accelerate economic development. Similarly, a quadruple helix approach is advocated in (Amaro et al. 2014) for Guatemala, a country vulnerable to extreme climate events 
that shows a lack of awareness for climate change effects and related action systems, and that could therefore benefit from a TH intervention integrated with civil society actors.

Finally, other authors criticized the underlying paradigm of the university role in a TH model, namely the concept of third mission pursued by an entrepreneurial university, highlighting how the adoption of market logics promoted profit over the technology transfer; the new mission for academic institutions should be that of "creating societal transformations in pursuit of realizing sustainable development" (Trencher et al. 2014). In this perspective, with the goal of materializing sustainable development in a specific context, a function of "co-creation for sustainability" is proposed for the university, beyond the conventional research and development and product improvement through innovation.

\section{Energy Access and Climate Change in Kenya}

\section{Country Overview}

Kenya is an equatorial country of about $580,000 \mathrm{~km}^{2}$ located in East Africa with significant different climate conditions varying from desertic to humid areas. With a gross domestic product (GDP) of 87.9 billion USD in 2018 with an average growth rate of about $9 \%$ in the past 10 years and a population of about 51.4 million people in 2018, Kenya is experiencing a strong economic growth (World Bank 2020). In the last 20 years, the GDP per capita has grown steadily and even poor people have benefited as the poverty ratio decreased by $36 \%$ over the period.

However, the Sustainable Development is not achieved in Kenya; still many people live below the poverty line, rarely water is safely managed with even no basic service in 40\% of cases (UNICEF and WHO 2019), hunger significantly affects $10-40 \%$ of the children 5 year old or younger (FAO 2019), and sanitation and hygiene is even worse, also affecting maternity-related concerns (UNICEF and WHO 2019). Energy access is still limited: about $25 \%$ of people do not have access to electricity and an even larger proportion (75\%) have no clean cooking facilities (World Bank 2020). Altogether, inequalities are significant, as also proven by the high 40\% Gini index (2015) (World Bank 2020). Nevertheless, these problems have been decreasing.

In order to promote growth and tackle these challenges, the government has developed and implemented the Kenya Vision 2030 program in 2007 (Ministry of Planning and National Development 2007) with significant pillars based on macroeconomic stability, measures for the poor, capacity building, research, infrastructures, and energy. A new constitution was promulgated in 2010 and the corresponding legislation and administrative procedures have been set up the following year. The reform laid the bases for the decentralization of power into county-level governments able to develop local policies and tax reform accounting for the specific problems of the territory (Ministry of Planning and National Development 2007; Ngigi and Busolo 2019). The Devolution, which was ushered in 2013, 
has benefits in terms of a more equitable distribution of resources, economic and social development, political participation of citizens, enhanced transparency and accountability of governments, and even unity (Ngigi and Busolo 2019).

\section{Climate Change}

Kenya is vulnerable to climatic events, mainly droughts and floods. According to the National Adaptation Plan (NAP) launched in 2016 (Government of Kenya 2016), droughts have been recurring in the past 40 years, affecting millions of people by disrupting pastoral and agricultural activities, causing famine and population displacement. Floods, which are recurring phenomena as well, cause loss of human lives and damages to infrastructure, such as roads or power lines, hence potentially leading to problems to the transportation sector and the supplying of basic services to the population. Moreover, the areas subject to floods can experience the spreading of waterborne or sanitation-related diseases in the subsequent period (Government of Kenya 2016), as humid conditions ease the widespread of diseases, excrements and sewage are difficult to contain, especially in case of open defecation (UNICEF and WHO 2019), and the damaged infrastructure delay possible aid (Bündnis Entwicklung Hilft (Alliance Development Works) and United Nations University - Institute for Environment and Human Security (UNU-EHS) 2016). Given the damage and risks due to these extreme events, local and international entities have developed policies and dedicated programs for droughts and disaster risk management in Kenya, as detailed in Global Water Partnership Easter Africa (GWPEA) (2015).

\section{Rural Electrification in Kenya}

In Kenya Vision 2030, the "long-term development blueprint for the country" launched in 2007 (Ministry of Planning and National Development 2007), energy is considered a foundational infrastructure to enable the goals set out by the government on the economic, social, and political governance pillars. To address the specific issue of electricity access in rural areas, the Rural Electrification Authority (REA) was created in 2007, and then with the 2019 Energy Act adopted in March 2019 (Republic of Kenya 2019), REA has been changed to Rural Electrification and Renewable Energy Corporation (REREC). REREC has the mandate to develop and implement the rural electrification program of Kenya and to manage a dedicated Rural Electrification Programme Fund, also established by the Energy Act.

This choice reflects the change of pace in the country's objectives: the target for $100 \%$ electricity access in rural areas originally set out for 2030 (Rural Electrification Authority (REA) 2008) has been moved to 2022 in 2013 (Kenya Ministry of Energy 2018), as electricity is considered a key backbone for the achievement of the "big four agenda" (Republic of Kenya - The National Treasury and Planning 2018) pivoted on enhancing food security, universal healthcare, affordable housing, and 
increasing the GDP share of manufacturing and agri-processing activities. Kenya has been the fastest African country in closing the access gap, with an annualized increase in access of 6.4 percent points between 2010 and 2017, with a remaining deficit of 18 million people without access, corresponding to a $63.8 \%$ access rate in 2017 (IEA et al. 2019).

According to the national electrification strategy, universal access will be achieved mostly via grid intensification and densification (2.77 million connections), standalone solar systems (1.96 million connections), grid expansion (269,000 connections), and mini-grids (35,000 connections) (Kenya Ministry of Energy 2018).

Research showed that the mere presence of grid infrastructure in Kenya does not translate to high rate of consumer takeoff, even for "under grid" households that are within $200 \mathrm{~m}$ of a low voltage power line (Lee et al. 2014). To address this issue, the Last Mile Connectivity Program has been launched, to tackle the key issue of affordability of the connection fee, lowered from 398 to 171 USD, including the opportunity of paying in monthly installments.

On the other hand, the construction of the mini-grids, foreseen by the national electrification strategy, will fall under the Kenya Off-Grid Solar Access Project (KOSAP), started by the Ministry of Energy in July 2017 and financed by the World Bank (Ministry of Energy 2018). The project benefits 14 underserved counties in the northern and eastern regions of Kenya, including the Marsabit County, and envisages providing standalone systems, for dispersed users and public facilities, clean cookstoves, solar water pumps for community facilities, and minigrids in selected target communities. As per government data, the number grew to 151 after the field surveys (Ministry of Energy 2019a). It is worthy noticing that KOSAP integrates environmental concerns, citizen engagement, a capacity building component - also directed at county governments - and incentives for private sector involvement. The mini-grids to be developed under this framework, in fact, will be developed under a public-private partnership (PPP) lasting 7-10 years by which generation facilities will be co-funded by public and private actors, and distribution networks will be built with public funds only (KP and REA 2017). Until the PPP lasts, the O\&M of generation and distribution assets will be performed by a single private service provider (PSP), while the final users will be KP customers subject to the national tariff (KP and REA 2017); thereafter, all the assets, hence both the generation and distribution ones, will be owned by the Government of Kenya.

According to the National Electrification Strategy, the funding allocated on improving the national grid are about 2.3 billion USD over five years, accounting for about $82 \%$ of the total. The interventions are expected to focus on the installation of new transformers (grid densification), on the extension of existing MV lines up to $2 \mathrm{~km}$ to reach new customers (grid intensification) and also on the extension of the distribution system with longer lines expansion within $15 \mathrm{~km}$ the existing backbone (grid extension). These measures focus on areas relatively close to the existing network; yet, rural areas are not overlooked. In fact, about $18 \%$ of the funding will fund mini-grids and solar home systems (SHS) with the goal of reaching the people that cannot be reached by the other measures. SHS will receive more than ten times the funding with respect to mini-grids (Kenya Ministry of Energy 2018); yet, the 
potential for mini-grid development in Kenya may have been underestimated in the national planning strategy, as detailed in a series of technical reports and scientific papers (Ambition to Action 2019).

\section{Case Study - Marsabit County, Kenya}

In this section we describe the major activities in the view of the TH concept that have been developed in Marsabit, Kenya. The information reported here are based on the available literature and the knowledge of the experienced authors, also based on field work. Three case studies have been chosen for this book chapter due to the different types of conditions and information they represent.

\section{Overview}

Marsabit is one of the 47 counties created with the 2010 Constitution of Kenya, located in the northern part of the country, bordering Ethiopia. According to the most recent census, held in 2019, Marsabit has 459,785 inhabitants occupying a total of 67,000 square kilometers, making it the least densely inhabited county in Kenya, with an average population density of 6 persons $/ \mathrm{km}^{2}$ (Kenya National Bureau of Statistics 2019). The agroclimatic zones range between very-arid (zone VII) to semihumid/semi-arid (zone IV). The prevalent land cover is barren land (65.4\% of the total area), which is only fit for pastoralist activities (Wiesmann et al. 2016). Rural population engaged in agri-pastoral activities is largely nomadic, moving around the countryside according to the seasons in search of food, water, and grazing land.

The poverty rate in Marsabit registered with the 2009 census was $75.8 \%$, the fourth overall highest among Kenya, with a poverty severity of $8.8 \%$ with respect to a $4.89 \%$ national average (Wiesmann et al. 2016). The living conditions are very different among the various sub-counties and among towns and rural areas. All the settlements around the main northern road, which goes from Merile to Moyale and connects Kenya to Ethiopia, have the advantage of increased access to goods coming from all the county and benefit from the presence of numerous investors, which started setting foot in the region since devolution and significantly increased their presence during the last few years. In a comparative analysis done among Isiolo, Marsabit, and Meru counties, Marsabit exhibited the lowest resilience capacity index (FAO 2017). The main reason was a poor adaptive capacity, linked to low education levels and low income diversification, given the predominance of pastoral activities (FAO 2017).

Although the region is one of the lowest developed in Kenya, food insecurity affects a limited share of the population (10-15\%) given the large consumption of milk, but there is serious/critical malnourishment among above $15 \%$ of children and it is also stated that the whole population is even at significant risk of food insecurity in case of drought emergency (UNICEF 2017). Moreover, despite improvement in the years, water access is still a problem. Socioeconomic analyses revealed that only $26.4 \%$ of population above 3 year old is currently enrolled in school, whereas $63.4 \%$ 
of the population has never attended one (Kenya National Bureau of Statistics 2019). The typical economic activities are farming and livestock production, with a minority practicing fishing (1295 households out of 77,495), yet with no commercial-oriented business as the majority of households conduct these activities for subsistence (Kenya National Bureau of Statistics 2019). At the time of writing, the release of the 2019 census is still incomplete, so for other relevant data figures provided will refer directly or indirectly through secondary literature, to the 2009 census.

Given the climate and soil conditions, about $80 \%$ of the population is involved in pastoral production, a sector extremely vulnerable to not only recurrent droughts that have caused losses for over $60 \%$ of livestock in recent years but also floods that have also caused sweeping the cattle and killing them (The Ministry of Agriculture Livestock and Fisheries (MoALF) 2017). There are no perennial rivers but only four seasonal drainage systems (Marsabit County Government 2018); therefore, only $38.2 \%$ of the households have access to safe water (Wiesmann et al. 2016). The county is dependent on short rains for $80 \%$ of food security and on long rains for $20 \%$ (Kenya Food Security Steering Group (KFSSG) and Marsabit County Steering Group 2017). Moreover, the irrigated areas for the major crops (maize, tomatoes, and kales) declined also due to high maintenance costs for irrigation and low recharge of surface water sources (Kenya Food Security Steering Group (KFSSG) and Marsabit County Steering Group 2017).

Aiming to adapt to these challenges, some locals have attempted to develop activities such as water harvesting, value addition to local products, conservation of soil and water, tree planting, business diversification, selection of more resistant livestock types, yet in an insufficient and uncoordinated way, and the lack of access to electricity and good infrastructure are clearly additional barriers (The Ministry of Agriculture Livestock and Fisheries (MoALF) 2017). Deforestation in the lowlands in combination with droughts contributes to reduced water flows, health issues, and undermining of food security and strongly affects not only the living condition of the population but the farming businesses, agriculture targeting programs, and pastoralist pathways and lowers drastically the level of security due to land use conflicts (The Ministry of Agriculture Livestock and Fisheries (MoALF) 2017). Armed fights, which can also have a tribal nature across counties, result in human and livestock deaths, destruction of crops and homesteads, fear, and poverty.

\section{Energy Access in Marsabit}

Energy access in Marsabit County is restricted to urban centers, always supplied by off-grid solutions with the exception of the towns of Sololo and Moyale, which are interconnected to the Ethiopian national grid, thanks to their proximity to the border (Republic of Kenya and County Government of Marsabit 2018). A list of public mini-grids active in the county is provided in Table 1, the only known active private mini-grid in Table 2, and the list of 13 sites in which mini-grids will be built under KOSAP in Table 3. Also, a list of 26 medical, school, and public facilities to be 
Table 1 Operational public mini-grids in Marsabit (Nygaard et al. 2018; Ambition to Action 2019)

\begin{tabular}{|c|c|c|c|c|c|c|}
\hline $\begin{array}{l}\text { Off-grid } \\
\text { station }\end{array}$ & $\begin{array}{l}\text { Diesel } \\
(\mathrm{kW})\end{array}$ & $\begin{array}{l}\text { Solar } \\
(\mathrm{kWp})\end{array}$ & $\begin{array}{l}\text { Wind } \\
(\mathrm{kWp})\end{array}$ & $\begin{array}{l}\text { Battery } \\
\text { capacity (Ah) }\end{array}$ & Connections & $\begin{array}{l}\text { Commissioning } \\
\text { date }\end{array}$ \\
\hline Marsabit & 2900 & 0 & 500 & 0 & $\begin{array}{l}8200 \text { (June } \\
2016)\end{array}$ & 1977 \\
\hline $\begin{array}{l}\text { North } \\
\text { Horr }\end{array}$ & 184 & 0 & & 0 & $\begin{array}{l}160 \text { (June } \\
2016)\end{array}$ & 2016 \\
\hline Laisamis & 264 & 80 & & 27,816 & $\begin{array}{l}160 \text { (June } \\
2016)\end{array}$ & 2016 \\
\hline Illaut & 50 & 60 & 0 & 76,800 & 200 & 2019 \\
\hline Ambalo & 50 & 60 & 0 & 76,800 & 200 & 2019 \\
\hline Balesa & 50 & 60 & 0 & 76,800 & $\mathrm{n} / \mathrm{a}$ & 2019 \\
\hline Total & 3498 & 260 & 500 & 258,216 & 8920 & \\
\hline
\end{tabular}

Table 2 Operational private mini-grids in Marsabit (Blodgett et al. 2017; Nygaard et al. 2018)

\begin{tabular}{l|l|l|l|l}
\hline Mini-grid & Developer & Solar $(\mathrm{Wp})$ & Commissioning date & Customers \\
\hline Merile & Vulcan Inc. & 1.5 & 2014 & 27 \\
\hline
\end{tabular}

Table 3 Mini-grids to be built in Marsabit County under KOSAP (Ministry of Energy 2019a)

\begin{tabular}{l|l}
\hline Mini-Grid & Potential customers \\
\hline Bubisa & 329 \\
\hline Kargi & 379 \\
\hline South Horr & 496 \\
\hline Loiyangalani & 1051 \\
\hline El Gadhe & 108 \\
\hline Gatab & 299 \\
\hline
\end{tabular}

benefited by KOSAP intervention in the county has been published (Ministry of Energy 2019b). Finally, there are also private projects, however, often supported by international cooperation (KfW/GIZ/EnDEV) such as for the mini-grids to be developed in Dukana, Illeret, Ngurunit, Dabel, and Diridima (Energies Development 2018; Nygaard et al. 2018).

Moreover, although being a low developed area, there have been developed some large-scale projects in recent years. First of all, given the large wind power potential available in areas of the region, a large scale $310 \mathrm{MW}$ wind farm, representing about $15 \%$ of the installed capacity, has been developed close to lake Turkana and connected to the national grid in September 2018 (LTWP 2018). Furthermore, given the proximity with the Ethiopian border, a 263-km HVDC transmission line has been developed as part of the Eastern Electricity Highway Project interconnecting Kenya and Ethiopia (KETRACO 2018). Despite the location of these large electrification projects, the County has not benefited from them in terms of increased access to electricity because low energy demand does not justify the installation of substations. However, the projects have led to enhance and tarmac the 195-km road infrastructures connecting South Horr with Laisamis (code D371) and with Loiyangalani (code C77), with the objective of easing the transport of materials 
and equipment for the construction of the wind farm (Lake Turkana Wind Power Limited 2011). Moreover, under the LAPSSET project the tarmacking of the IsioloMoyale highway has been completed, with significant economic benefits and enhanced accessibility for the region (Republic of Kenya and County Government of Marsabit 2018). The next step of the project, to be developed in future years, is the development to complete the corridor with a railway line (Republic of Kenya and County Government of Marsabit 2018).

The increased level of economic activities along the Isiolo-Moyale road is also visible as shops and residential houses are quickly sprouting by the highway. Local people are moving slowly from pastoralism to different types of business in this area or are using part of their herd to try and invest in diverse activities.

The Marsabit County set out the development of renewable energy sources as a recommendation for climate change mitigation and adaptation, aspiring to exploit the solar and wind potential of the region (Republic of Kenya and County Government of Marsabit 2015). However, the same document stated the lack of human capacity and investment opportunities as barriers for development of energy projects, as well as high fuel costs in construction machineries that hinder investments (Republic of Kenya and County Government of Marsabit 2015).

During the 2013-2017 period, the county provided over 2000 energy saving charcoal burners (jikos) to households, 417 solar street poles, and distributed solar panels to schools with the goal of improving the household reliance on biomass and kerosene that can significantly affect the health of people (Republic of Kenya and County Government of Marsabit 2018). While the goal for solar street poles set out in the previous integrated development plan has been exceeded, the other targets for the distribution of 500,000 jikos, start-up of a solar equipment enterprise, installation of solar pump driven boreholes, and construction of a power station per constituency have not been fulfilled yet (Republic of Kenya and County Government of Marsabit 2015, 2018).

In the current development plan, not only the previous targets have been restated and expanded but also specific funds have been dedicated for Centre for Renewable Energy Studies and Research of Marsabit County (Republic of Kenya and County Government of Marsabit 2018) to help overcome the knowledge gaps limiting the supply of energy to the population.

\section{Marsabit Town}

Marsabit Town is the main town in the county and is situated on an isolated extinct volcano, Mount Marsabit, where the environmental conditions are completely different from the rest of the region.

Devolution, started in 2013, had a broad impact on the development of Marsabit Town that became the county government headquarter, thus, not only the center of all international organizations operating in the county but even of all the various ministries of regional government. As a result, the town is attracting a growing number of investors with several companies setting up business and effectively 
opening up the northern frontier region market. Marsabit market, especially during Saturdays, became the first market in the County. Cereals and legumes are imported directly from Ethiopia, while vegetables come from the area around Meru. Between 2013 and the 2019 more than 40 schools were built and one level 5 hospital, in addition to the one run by CARITAS. In the town there is the presence of numerous clinics and dispensaries, mostly in the scattered sublocations. Marsabit Town currently has more than 50 primary schools, 15 secondary ones, and 2 technical institutes, accounting both public and private institutions. All the secondary schools and most of the primaries are electrified, reflecting as per the first phase of REA's strategic plan for 2008-2012 (Rural Electrification Authority (REA) 2008).

The town is served by a mini-grid installed by REREC and operated by Kenya Power with an installed capacity of 3.1 MW (2.6 MW from three diesel generators and $500 \mathrm{~kW}$ from wind turbines). The system was commissioned in 1977, with the generation capacity growing steadily and number of connections steeply rising, especially after devolution came into place. As most of the public infrastructure has then been built and reaching around 8200 customers as per June 2016. The medium voltage lines used to connect the public facilities have then been used to give access to households located within 600 meters of an existing transformer, with the uptake from final users facilitated by the Last Mile Connectivity Program which lowered the upfront cost of connections. Consequently, most of the connected households are either located in the town center where most of the business activities take place, or in the vicinity of schools, hospitals, or dispensaries and county government buildings, but also the areas surrounding the town are slowly benefiting from the ramp-up in electricity access.

Water access is the primary issue of the population residing in the town. The water table is very deep, due to the characteristics of the volcanic soil, and the main source of water are shallow wells in the forests, water boozer coming from boreholes in the nearby settlements or through water harvesting.

National government programs focusing on floods and droughts resilience were already deployed before devolution, but through the county government presence in the town, the solutions have been increasingly adapted to the specific context collaborating directly with the NGOs operating locally, local associations and cooperatives. Numerous projects and training programs have been carried out on water harvesting, water management, and small-scale agriculture as focused programs on seeds restocking and drought-resistant crops.

\section{Illaut}

Illaut is a town located in the south-western part of Marsabit, near the border with Samburu county. Illaut, after the rehabilitation of the existing Laisamis-Ngurunitllaut-South Horr-Loiyangalani road, funded by the African Development Bank and the Government of the Netherlands to connect the Wind Farm developed on the shore of Lake Turkana, became a central point of connection for all the surrounding areas. The chief of Illaut is responsible for everyone living in all the nearby villages. 
In consideration of its relevance, Illaut has been selected as one of 26 sites for the installation of hybrid mini-grids by REREC (REREC 2019). The system was commissioned in October 2019, with around 20 customers connected (two shops, one church, and one dispensary plus households). Due to the lack of Internet connectivity, the smart-metering system is still not operating at the present time, while power generation and consumption is steady. Having network access is in fact mandatory for the KP metering systems, as to collect the revenues, monitor consumption, and bill collection is a big hurdle for most of the new hybrid mini-grids operated by Kenya Power. However, Safaricom started building a repeater tower in the end of 2019, which is supposed to start working during spring 2020, to grant network access to the Illaut and the nearby villages. Access to the network has been proven to bring direct economic and social benefits for everyone: mobile and Internet services have a transformational impact, offering life-enhancing financial and health services, as well as the simple ability to enhance communication within families and within the whole community.

Most of the houses are made out of bricks and the Tuesday market became the main trading post for goods coming from Meru and Nairobi, through Marsabit and Nyeri, and for local handmade products. The presence of a nearby shallow well provides access to water that has to be treated to be drinkable. This is not perennial and depends on rainfall, making it hard for people to access water during the longlasting dry season.

Firewood is the primary source for cooking, followed by charcoal. In Illaut town local government is creating awareness regarding the negative that open fire has on the health of mainly women and children.

In the end of 2019 the county government, following the access to water plan of the Water Resources Management Authority (WARMA), started building a borehole in the town that will be completed in early 2020. Thanks to this borehole the town, and the nearby settlements, can have access to clean water that can be used for irrigation and cattle survival during the dry season. The chief of the village, together with key personalities of the community, has been engaging both the farmer communities in Marsabit and Laisamis, NGOs like PACIDA, and some SACCOs to obtain training, seedlings, and agriculture machines to open up the possibility of unlocking the potential of local farmers.

Illaut can be considered as an example of sustainable development and climate change resilience through the TH model, due to:

- Improvement of the infrastructure by the government (Laisamis-Loiyangalani road funded by AfDB).

- Electrification through a hybrid system by REREC (60 kW) (Rural Electrification Master Plan).

- Construction of a borehole and installation of a pumping system for human and agriculture use by the county government (WARMA access to clean water program).

- Installation of a repeater for the network access by Safaricom (private company intervention). 


\section{Laisamis}

Laisamis is the main town of Laisamis constituency. It is situated between Merile and Log-logo, on the road from Isiolo to Marsabit Town. In Laisamis most of the buildings are made out of bricks, but most of the people in the surrounding areas are living in huts. Along the road there is the presence of schools, hospitals, shops, hotels, and other business which are benefiting from affordable and reliable energy access.

Laisamis is served by a hybrid mini-grid commissioned by REREC in 2015 that currently serves 170 connected customers, mostly concentrated around the tarmac road and near the town center, where the majority of shops and activities are located. The system that combines $264 \mathrm{~kW}$ of diesel generators, $80 \mathrm{~kW}$ of solar photovoltaic, and a battery storage system experienced a significant growth of connections thanks to the implementation of the last-mile project. Furthermore, an expansion of the system to reach the communities of Log-logo and Merille started 2 years ago, and the main distribution infrastructure, transformers, and low voltage lines have been put in place in early 2020, but are not yet operational.

Merille and Log-Logo are two urban centers located, respectively, $23 \mathrm{~km}$ south and $47 \mathrm{~km}$ North of Laisamis. In both towns there is presence of numerous boreholes that are powered by PV systems or diesel generators for shops, dispensaries, and schools. The interconnection of the systems foresees the installation of an additional $500 \mathrm{~kW}$ diesel generator to provide adequate electricity supply. This is creating a big opportunity for people to benefit from energy access through income-generating activities.

In Laisamis, access to water is granted by a seasonal river and different private and public boreholes scattered around town. In fact, the water table is not deep, and as results of surveys by the county government and WARMA suggest there is a good potential to dig boreholes. During dry season the sources of water, for the majority of the people, are two public boreholes in the north west of the main settlement, where they can access water for free, but in limited quantities. The salinity level of the water extracted is high and has to be treated accordingly.

\section{Discussion}

The selected case studies in Marsabit are evaluated with respect to the theoretical framework laid out in section "The Triple Helix," and in consideration of the literature review detailed in section "Energy Access and Climate Change in Kenya." Although the analysis has been carried out for Marsabit County, a great part of it can be replicated in the other 13 underserved counties identified by KOSAP.

An interesting aspect of this ecosystem is that NGOs have been attempting to improve local conditions by capacity building which can be done by locally present technical schools, vocational training centers, and Technical and Vocational Education Training (TVET) centers. In the proposed cases, in fact, NGOs have developed projects on agriculture and drought resilience species. It was also noted that some electrification activities have also been directly promoted by NGOs, but some projects have failed because the system has not been maintained. Here is when one sees 
the difference between NGOs and private sector partners. The latter will not leave as long as there is a market for the goods or services rendered.

In the three case studies reported above, water pumping from boreholes or close water sources is significant priority and is usually performed when the village is electrified and water is available nearby. The devolution that started taking place in 2013 has actually helped the county in addressing these problems.

The positive example of Laisamis has shown that combining energy with a safe source of water for people and animals has reduced the nomadism of the area, thus making the electric system more sustainable. Another useful information is an accurate estimate of the population able and willing to purchase energy from the mini-grid. As a matter of fact, load assessment is one of the most critical challenges in mini-grid development.

From the case study analysis, it appears that there is a growing attention in policymaking to the transversally and interdependence of key rural challenges such as energy access, climate change adaptation, and water and food security. Even if not explicitly mentioned, partial references to the $\mathrm{TH}$ approach are each day more present in the planning phase though the "silo mentality" that persists.

Education plays a significant role in terms of both enhancing awareness of technologies, opportunities, safe practices, and hygiene in the area and developing skills to promote growth. Currently there are eight vocational training centers (VTCs) in the county that provide above-basic education, four of them instituted by the county government. These centers nonetheless are not yet accredited by the Technical and Vocational Education and Training Authority (TVETA).

It is worth noticing the case of Illaut in which a repeater has been installed shortly after the mini-grid was installed. In fact, people look for connection as a modern mini-grid operator needs connectivity to operate, monitor, and manage the smart-metering system.

Considering this, universities can support and study all the above and identify best practices as well promote new solution to tackle the issues. For example, in Laisamis, the electricity service suffers from poor quality and outages, and the system will be soon enlarged to electrify the nearby villages. However, this may lead to increased number of outages and reduced quality given the long lines to reach the communities. This could be an opportunity for a university research center to provide support by analyzing the data in the field and promoting innovation also by field experience (mode 2). Social data combined with electrical data from the villages can be analyzed in order to estimate and promote the major determinants for load growth and even support the expansion of the mini-grid (Lee et al. 2014).

From the literature review on the $\mathrm{TH}$, it is evident that when government, university, and industry work together in good coordination, rural electrification and climate change adaptation problems are easier to solve.

In a society in which innovation is one of the major drivers for growth, a good application of $\mathrm{TH}$ to rural electrification can be not only a promising solution but also promote growth by developing innovation in a challenging and new sector in which few players operate. Besides, electricity provided by decentralized solutions such as mini-grids can be not only an economic solution for areas but provide services that can help people to stop the nomadic lifestyle. Many Turkana people are building permanent houses where the wives and children can stay in a place and 
profit from education, health service, and electricity while their husbands move around in search of water and grazing fields for their animals.

Rural electrification is a very risky business and rarely can achieve bankability without external funds. However, it brings significant benefits to society in terms of externalities such as local growth, the development of business activities, higher education for children, improved healthcare conditions, and connectivity, to quote but a few services. Therefore, the public sector that looks at society as a whole should be interested in fostering activities and reduce barriers to rural electrification, with tools such as tax exemption, green line of credit, and grants by developing agencies.

The involvement of university in the process can promote innovation by preexisting knowledge (mode 1), exploiting the field experience (mode 2), and also promoting capacity building for engineers, technicians, and students to provide the desired skills at county level. Therefore, alongside the "mode 2," which justifies the recourse of case studies, the "mode 3" of knowledge production that is based on pluralism and diversity ought to be used.

Additionally, it turns out that the TH concept for rural electrification and climate change might be extended including civil society and concern for natural environment conservation, which have been included respectively as the fourth and fifth helices, respectively, in the work described in Carayannis et al. (2019). Also the concept of "bottom-up triple helix" (Haas et al. 2016) is a valuable contribution toward a better understanding of the role of connector agents, financing institutions, market facilitators, and knowledge brokers. In short, a TH intervention for the development of vulnerable areas promotes the joint action of several entities.

In fact, there is for local universities not only the need to improve their research standards and improvement of curriculums to go beyond the training of workforce but also the mandate to carry out the capacity building of technicians and governmental actors (Perez-Arriaga et al. 2018) and to act as knowledge brokers in order to reach the final rural beneficiaries. In this sense, if we consider that, for example, Nairobi and Marsabit town are located more than $500 \mathrm{~km}$ apart, connector agents are needed even within a country in order to promote innovation by experience (mode 2 ). This specific issue has been addressed in Da Silva et al. (2018) that describes an outreach program to train solar PV technicians on the standards of the Kenyan Energy Regulatory Commission (ERC). The project represents a multi-stakeholder interaction involving academia (Strathmore Energy Research Centre (SERC)), donor agencies (USAID, GIZ), regulatory institutions (National Industrial Training Authority (NITA), ERC) and technical training institutions (TTI) which through "training of trainers" received the capacitation from SERC to train technicians in locations distant from Nairobi.

\section{Conclusions}

This chapter has shown that the collaboration of government, universities, and industry in a Triple Helix (TH) framework can be a promising tool for tackling rural electrification and climate change adaptation, using as example the Marsabit County, Kenya, case study. 
One such lesson was the need to add to the traditional TH concept the civil society which can provide a soft landing for the private sector partner which at the initial stage may not see significant opportunities for business sustainability.

In modern knowledge-based society, the role of academia in promoting innovation is crucial, and rural electrification sector is not an exception. The university can identify best practices, develop research studies on the possible outcomes of different actions, and even support the development of novel devices, by working closely with the two other partners and having enough data to work with, which are very precious for the effectiveness of the studies.

In Marsabit, which is one of the least developed counties in Kenya, there have been limited examples of $\mathrm{TH}$ interventions, but the potential can be significant. Government can provide an adequate policy framework and/or fiscal stimulus, driven by the industry's needs, lowering barriers and reducing risks, after being discussed and agreed with the other stakeholders. Industry can make use of the innovation created by this environment and thrive, hence employing local people and boosting the economy.

The concepts discussed in this study can be useful for policy makers and players in the rural electrification, since they can be easily generalized for different areas in Kenya and Sub-Saharan Africa.

\section{References}

African Development Bank Group, Sustainable Energy For All - Africa Hub, Sustainable Energy Fund for Africa (2016) Green mini-grids in sub-Saharan Africa: analysis of barriers to growth and the potential role of the African Development Bank in supporting the sector. GMG MDP Doc Ser $n 1$

Amaro N, Ruiz C, Fuentes JL et al (2014) Strategic contributions to extreme climate change: the innovation helixes as a link among the short, medium and long-terms. Clim Chang Manag:107122. https://doi.org/10.1007/978-3-319-04489-7_8

Ambition to Action (2019) The role of renewable energy mini-grids in Kenya's electricity sector. Evidence of a cost-competitive option for rural. electrification and sustainable development

Bagley C, Brown E, Campbell B, et al (2018) Mapping the UK Research \& Innovation Landscape: Energy \& Development

Blodgett C, Dauenhauer P, Louie H, Kickham L (2017) Accuracy of energy-use surveys in predicting rural mini-grid user consumption. Energy Sustain Dev 41:88-105. https://doi.org/ 10.1016/j.esd.2017.08.002

Bündnis Entwicklung Hilft (Alliance Development Works), United Nations University - Institute for Environment and Human Security (UNU-EHS) (2016) World Risk Report 2016

Carayannis EG, Acikdilli G, Ziemnowicz C (2019) Creative destruction in international trade: insights from the quadruple and quintuple innovation Helix models. J Knowl Econ. https://doi. org/10.1007/s13132-019-00599-z

Carayannis EG, Campbell DFJ (2010) Triple helix, quadruple helix and quintuple helix and how do knowledge, innovation and the environment relate to each other? A proposed framework for a trans-disciplinary analysis of sustainable development and social ecology. Int J Soc Ecol Sustain Dev 1:41-69. https://doi.org/10.4018/jsesd.2010010105

Da Silva I, Geoffrey R, Nalubega T, Njogu M (2018) Replacing fossil fuel with PV systems through technical capacity building in Kenya. In: Leal Filho W, Surroop D (eds) The Nexus: energy, environment and climate change, green energy and technology. Springer, Cham, pp 171-180 
Da Silva I, Wassler S (2011) Implementation of triple Helix clusters procedure in the sub-Sahara Africa energy sector. Case study: academia - CREEC photovoltaic laboratory. In: Conference MPDES 2011

Dzisah J (2011) Mobilizing for development: putting the triple helix into action in Ghana. In: Saad M, Zawdie G (eds) Theory and practice of the triple Helix system in developing countries: issues and challenges. Routledge, New York, pp 146-160

Energies Development (2018) Call for proposals for development of solar PV hybrid mini-grids in Marsabit county

Etzkowitz H (2008) The triple Helix: university-industry-government innovation in action. Routledge, New York

Etzkowitz H (2003) Innovation in innovation: the triple Helix of university - industry - government relations. Soc Sci Inf 42:293-337. https://doi.org/10.1023/A:1026276308287

Etzkowitz H (2012) Silicon Valley: the sustainability of an innovative region. Soc Sci Inf 52:1-25. https://doi.org/10.1177/0539018413501946

Etzkowitz H, Zhou C (2006) Triple Helix twins: innovation and sustainability. Sci Public Policy 33:77-83. https://doi.org/10.3152/147154306781779154

FAO (2017) Resilience analysis in Isiolo, Marsabit and Meru. Anal Resil Target Action FAO Resil Anal 9

FAO (2019) Food security and nutrition in the world

Franz M, Peterschmidt N, Rohrer M, Kondev B (2014) Mini-grid policy toolkit

Fraval S, Hammond J, Bogard JR et al (2019) Food access deficiencies in sub-saharan Africa: prevalence and implications for agricultural interventions. Front Sustain Food Syst 3. https://doi. org/10.3389/fsufs.2019.00104

Gambino V, Del Citto R, Cherubini P et al (2019) Methodology for the energy need assessment to effectively design and deploy mini-grids for rural electrification. Energies 12(12):574. https:// doi.org/10.3390/EN12030574

Gibbons M, Limoges C, Nowotny H et al (1994) The new production of knowledge. The dynamics of science and research in contemporary society. SAGE, London

Global Water Partnership Easter Africa (GWPEA) (2015) Assessment of drought resilience frameworks in the horn of Africa. Integr Drought Manag Progr Horn Africa (IDMP HOA

Goldemberg J, Martinez-Gomez J, Sagar A, Smith KR (2018) Household air pollution, health, and climate change: cleaning the air. Environ Res Lett 13. https://doi.org/10.1088/1748-9326/aaa49d

Government of Kenya (2016) Kenya National Adaptation Plan: 2015-2030

Haas R, Meixner O, Petz M (2016) Enabling community-powered co-innovation by connecting rural stakeholders with global knowledge brokers: a case study from Nepal. Br Food J 118:1350-1369. https://doi.org/10.1108/BFJ-10-2015-0398

IEA, IRENA, UNSD, et al (2019) Tracking SDG7: the energy Progress report

International Energy Agency (IEA) (2019a) World energy outlook

International Energy Agency (IEA) (2019b) Africa energy outlook 2019

Kenya Food Security Steering Group (KFSSG), Marsabit County Steering Group (2017) Marsabit County 2017 long rains food security assessment report

Kenya Ministry of Energy (2018) Kenya National Electrification Strategy: key highlights 2018

Kenya National Bureau of Statistics (2019) Kenya Population and Housing Census. https:/www. knbs.or.ke/?p=5621. Accessed 1 Mar 2020

KETRACO (2018) KETRACO Grounbreaks Community Projects in Marsabit

Kimatu JN (2015) Evolution of strategic interactions from the triple to quad helix innovation models for sustainable development in the era of globalization. J Innov Entrep 5:0-6. https:// doi.org/10.1186/s13731-016-0044-x

Kottász E, Draeck M (2017) Renewable energy-based mini-grids: the Unido experience

KPLC, REA (2017) Kenya off-grid solar access project (KOSAP). Vulnerable \& Marginalized Groups Framework

Lake Turkana Wind Power Limited (2011) Addendum on Road Re-Alignment Environmental and Social Impact Assessment (ESIA) Report for the proposed Strengthening of Laisamis-South (D371) and South Horr- Loiyangalani (C77) Road 
Lee K, Brewer E, Christiano C et al (2014) Barriers to electrification for "under grid" households in rural Kenya. Center for Effective. Global Action, Berkeley

Leydesdorff L, Etzkowitz H (1995) The triple Helix - university-industry-government relations: a laboratory for knowledge base economics development. EASST Rev 14:14-19

LTWP (2018) Lake Turkana wind power connected to the National Grid

Marsabit County Government (2018) Climate change mainstreaming guidelines: water and sanitation sector

Micangeli A, Del Citto R, Kiva I et al (2017) Energy production analysis and optimization of minigrid in remote areas: the case study of Habaswein, Kenya. Energies 10:2041. https://doi.org/ $10.3390 /$ en 10122041

Ministry of Energy (2018) The Kenya off-grid solar access project. K-OSAP

Ministry of Energy (2019a) KOSAP List of 151 Minigrids - Status after Field Survey (2)- Final (3)

Ministry of Energy (2019b) KOSAP Public Facilities by County - Status Final after Survey (3)

Ministry of Planning and National Development K (2007) Kenya vision 2030: a competitive and prosperous Kenya

Moore A, Nyangoma V, Du Toit J et al (2015) Rwandan collaborative model for educator capacity building. ICSIT 2018 - 9th Int Conf Soc Inf Technol Proc 16:167-172

Murphy B, Corbyn D (2013) Energy and adaptation. Exploring how energy access can enable climate change adaptation. Pract Action Consult

Ngigi S, Busolo D (2019) Devolution in Kenya: the good, the bad and the ugly. Public Policy Adm Res 9:9-21. https://doi.org/10.7176/PPAR

Nygaard I, Gichungi H, Hebo Larsen T, et al (2018) Market for integration of smaller wind turbines in mini-grids in Kenya

Outamha R, Belhcen L (2020) What do we know about university-industry linkages in Africa? In: Abu-tair A, Abdelmounaim L, Khalid AM, Bassam A-H (eds) Proceedings of the II international triple Helix summit. Lecture notes in Civil Engineering Volume, vol 43. Springer, Cham, pp 375-391

Perez-Arriaga I, Micangeli A, Sisul M (2018) Unleashing sustainable human capital through innovative capacity the micro-Grid's potential the micro-grid academy can unlock building and vocational training: in East Africa. Unlocking value from. Sustain Renew Energy:100-105

Republic of Kenya (2019) The energy act, 2019. Kenya Gaz Suppl

Republic of Kenya - The National Treasury and Planning (2018) Third medium term plan 20182022. Transforming lives: advancing socio-economic development through the "big four"

Republic of Kenya County government of Marsabit (2018), Second County integrated development plan 2018-2022

Republic of Kenya, County Government of Marsabit (2015) Revised First County Integrated Development Plan (2013-2017)

REREC (2019) Successor of rural electrification authority is now established. Rural Electrification Authority is now REREC

Res4Africa (2019) Water-Energy-Food Nexus - RES4Africa Foundation. https://www.res4africa. org/water-energy-food-nexus/. Accessed 21 Oct 2019

Rural Electrification Authority (REA) (2008) Strategic plan 2008-2012

Smith KR, Bruce N, Balakrishnan K et al (2014) Millions dead: how do we know and what does it mean? Methods used in the comparative risk assessment of household air pollution. Annu Rev Public Health 35:185-206. https://doi.org/10.1146/annurev-publhealth-032013-182356

The Ministry of Agriculture Livestock and Fisheries (MoALF) (2017) Climate risk profile for Marsabit County. Kenya County climate risk profile series. Nairobi

Trenberth KE, Dai A, van der SG et al (2014) Global warming and changes in drought. Nat Clim Chang 4:17-22

Trencher G, Yarime M, McCormick KB et al (2014) Beyond the third mission: exploring the emerging university function of co-creation for sustainability. Sci Public Policy 41:151-179. https://doi.org/10.1093/scipol/sct044

UNICEF (2017) Situation analysis of children and women in KENYA. 224 
UNICEF, WHO (2019) Progress on drinking water, sanitation and hygiene. Who:1-66. https://doi. org $/ 10.1111 /$ tmi.12329

Wiesmann U, Kiteme B, Mwangi Z (2016) Socio-Economic Atlas of Kenya: Depicting the National Population Census by County and Sub-Location

World Bank (2020) Kenya Data. https://data.worldbank.org/country/kenya. Accessed 28 Mar 2020

Zhang J, Deng S, Shen F et al (2011) Modeling the relationship between energy consumption and economy development in China. Energy 36:4227-4234. https://doi.org/10.1016/j. energy.2011.04.021

Open Access This chapter is licensed under the terms of the Creative Commons Attribution 4.0 International License (http://creativecommons.org/licenses/by/4.0/), which permits use, sharing, adaptation, distribution and reproduction in any medium or format, as long as you give appropriate credit to the original author(s) and the source, provide a link to the Creative Commons license and indicate if changes were made.

The images or other third party material in this chapter are included in the chapter's Creative Commons license, unless indicated otherwise in a credit line to the material. If material is not included in the chapter's Creative Commons license and your intended use is not permitted by statutory regulation or exceeds the permitted use, you will need to obtain permission directly from the copyright holder.

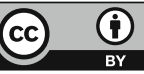

